\title{
Chemical composition, antioxidant, anticholinesterase and anti-urease activities of Sideritis pisidica Boiss. \& Heldr. endemic to Turkey
}

\author{
Ebru Deveci, Gülsen Tel-Çayan, Hasan Yıldırım, Mehmet Emin Duru
}

\begin{abstract}
The objective of this study was to investigate the chemical composition, antioxidant, anticholinesterase and anti-urease activities of essential oil, hexane, acetone and methanol extracts of Sideritis pisidica Boiss. \& Heldr. The essential oil and fatty acid composition were analyzed by GC and GC/MS. $\delta$-Cadinene (19.5\%), T-cadinol (16.7\%) and $\beta$-cubebene (10.4\%) were identified as the main compounds of the essential oil whereas the most abundant compounds of fatty acids were found as linolenic (42.7\%), palmitic (31.3\%) and linoleic (13.4\%) acids.
\end{abstract}

The methanol extract demonstrated the highest antioxidant activity in all tests, except for metal chelating assay. The hexane extract was found to be significantly active in metal chelating $\left(\mathrm{IC}_{50}: 22.97 \pm 1.36 \mu \mathrm{g} / \mathrm{mL}\right)$, acetylcholinesterase $(62.54 \pm 0.88 \%)$ and urease inhibitory $(78.93 \pm 0.17 \%)$ assays. These results show that the Sideritis pisidica could be used as the potential source of natural products in the food and pharmaceutical areas.

Key words: Sideritis pisidica; essential oil; fatty acid; antioxidant activity; anticholinesterase activity; anti-urease activity
Ebru Deveci, Mehmet Emin Duru

Department of Chemistry, Faculty of Science, Muğla Sıtkı Koçman University, Muğla, Turkey

Gülsen Tel-Çayan

Department of Chemistry and Chemical Processing Technologies, Muğla Vocational School, Muğla Sitkı Koçman University, Muğla, Turkey

Hasan Yildirim

Department of Biology, Faculty of Science, Ege University, Izmir, Turkey

Corresponding Author:

Gülsen Tel-Çayan

e-mail:gulsentel@mu.edu.tr;gulsentelcayan@gmail.com

Submitted / Gönderilme: 28.04.2017 Revised / Düzeltme: 25.05.2017

Accepted / Kabul: $\quad 09.06 .2017$

How to cite this article : Deveci E, Tel-Çayan G, Yıldırım H, Duru ME. Chemical composition, antioxidant, anticholinesterase and anti-urease activities of Sideritis pisidica Boiss. \& Heldr. endemic to Turkey. Marmara Pharm J 2017; 21 (4): 898-905

\section{Introduction}

The Sideritis genus, a member of the Lamiaceae family, has more than 150 species which are distributed in tropical and mild regions of the Northern Hemisphere. The highest biodiversity of these species is found in the Mediterranean area especially Greece and Turkey [1-3]. Sideritis species are known as "mountain tea" in Anatolia and consumed as tea, flavoring agents and for medicinal purposes in various regions. Sideritis pisidica Boiss. \& Heldr. is called çay çalbası [4] and eldiven çayı [5] by local people. Up to now, several biological activities such as antioxidant, anticonvulsant, antispasmodic, anti-inflammatory, anti-rheumatic, antiulcer, antimicrobial, cytotoxic, and analgesic have been reported from Sideritis species [6-9].

In earlier studies, phenolic acids, steroids, diterpenoids, fatty acids, flavonoids, iridoid and phenylethanoid glycosides have been reported in Sideritis species [10-13]. In addition, the biological activity of extracts, essential oils and isolated pure compounds from these species were reported [10, 11, 14-18]. There are some chemical studies performed on S. pisidica. Up to date, the essential oil [19-22] and fatty acid [23] compositions of S. pisidica have been studied. Also, antioxidant, antiacetylcholinesterase activity and phenolic composition of the aqueous and ethanolic extract of S. pisidica have been reported by Erdogan-Orhan et al. [24] and Özkan [12]. 
So far, no study has been reported about antioxidant and enzyme inhibitory activities of the essential oil and the hexane, acetone and methanol extract of S. pisidica with the total phenolic and flavonoid contents. The aim of this study was to determine chemical composition, antioxidant, anticholinesterase and anti-urease activities of the essential oil and the hexane, acetone and methanol extract of S. pisidica with the total phenolic and flavonoid contents.

\section{Results and Discussion}

\subsection{Essential oil composition}

The chemical composition of the essential oil of S. pisidica was analyzed by GC-FID and GC/MS techniques. The chemical composition of the essential oil, relative percentage (\%) and
Kovats indices of compounds are given in Table 1. Thirtyone compounds, representing about $99.9 \%$ of the essential oil of $S$. pisidica were identified. The major compound was $\delta$-cadinene $(19.5 \%)$, followed by T-cadinol $(16.7 \%)$ and $\beta$-cubebene (10.4\%). The most abundant compounds in the essential oil were sesquiterpene hydrocarbons (56.1\%) and oxygenated sesquiterpenes (39.2\%), respectively.

In previous studies, the essential oil composition of S. pisidica was reported [19-22]. In these studies, $\alpha$-pinene, $\beta$-pinene, myrcene, $\alpha$-bisabolol, sabinene, $\beta$-caryophyllene, eugenol, thymol and camphor were identified as major compounds. When our findings were compared with the literature, the results showed some qualitative and quantitative differences between the compounds of the essential oils. The chemical composition of the essential oil of S. pisidica can be influenced

Table 1. Chemical composition of the essential oil of Sideritis pisidica

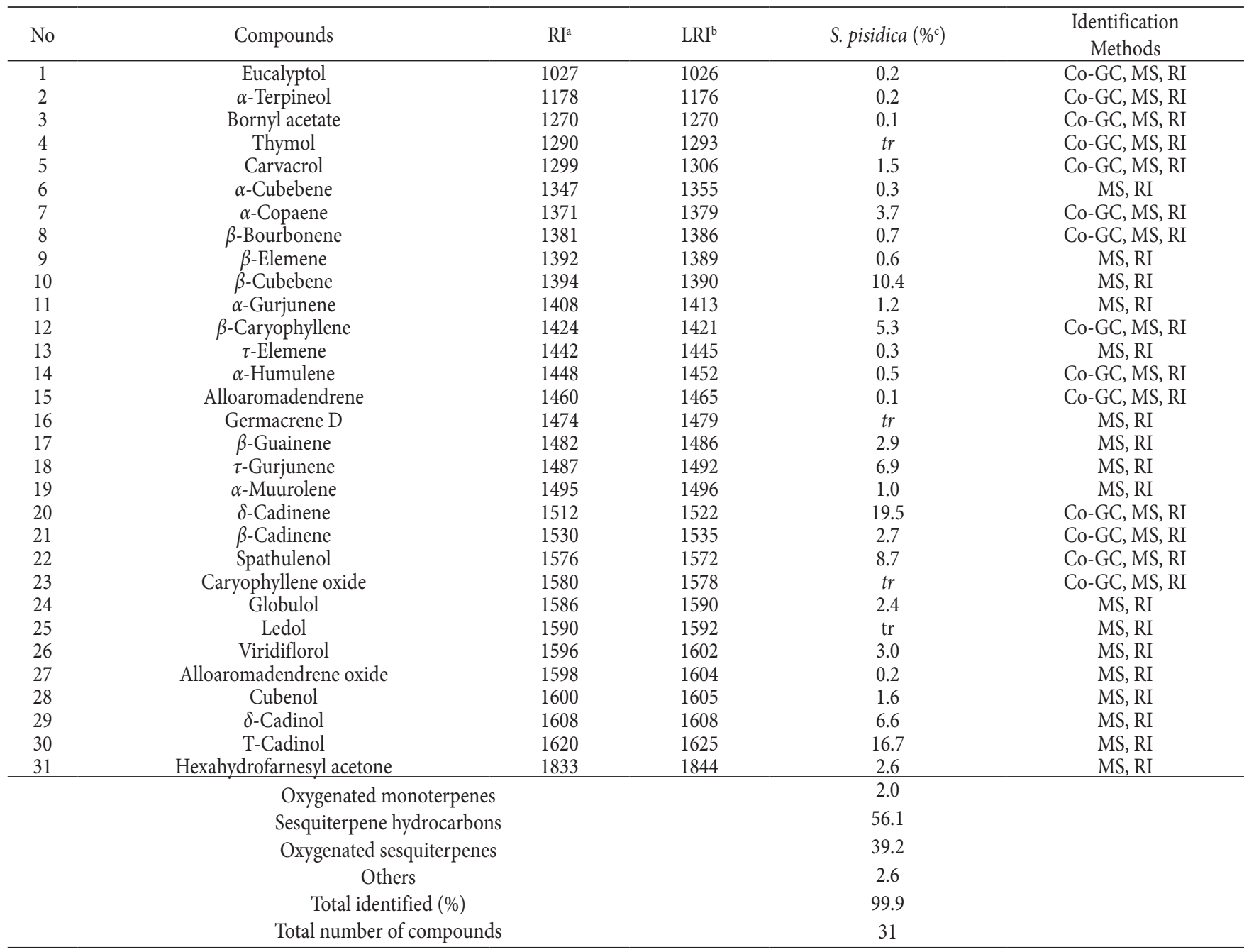

a: Retention indices on DB-5 fused silica column, b: Retention indices of literature on DB-5 column (33), c: Percentage concentration, Co-GC: Co-injection with authentic compounds, ${ }^{\text {RI }}$ : Retention Index literature comparison, ${ }^{\text {tr }}$ : trace 
by season, the geographical location and date of collection [25].

\subsection{Fatty acid composition}

The fatty acid composition of the aerial parts of $S$. pisidica was analyzed with GC-FID and GC/MS techniques. Table 2 shows the fatty acid composition of S. pisidica. Totally, nine fatty acids, ranging from $\mathrm{C}_{14: 0}$ to $\mathrm{C}_{24: 0}$ were detected. The major fatty acids were linolenic $(42.7 \%)$, palmitic (31.3 $\%)$ and linoleic acids (13.4\%). Linolenic acid known as the essential fatty acid for human metabolism was found to be the major fatty acid of $S$. pisidica. The total unsaturated fatty acid percentage was found as $62.9 \%$ and linoleic and oleic acid ratio (L/O) was 1.97. Oleic acid (6.8\%), stearic acid (4.1 $\%)$ and behenic acid (1.6\%) were found in small quantities while other fatty acids were determined in trace amounts. Ertan et al. [23] previously studied the fatty acid composition of the seeds of 15 Sideritis species including S. pisidica. The fatty acid composition of leaves and flowers of Lamiaceae were mainly composed of $\left(\mathrm{C}_{18: 3}\right)$ linolenic acid $[23,26]$.

Table 2. The fatty acid composition (\%) of S.pisidica

\begin{tabular}{lc}
\hline Fatty acids & $\begin{array}{c}\text { Sideritis pisidica } \\
(\%)\end{array}$ \\
\hline Tetradecanoic acid $\left(\mathrm{C}_{14: 0}\right)$ & $\operatorname{tr}^{\mathrm{b}}$ \\
Palmitic acid $\left(\mathrm{C}_{16: 0}\right)$ & 31.3 \\
Linolenic acid $\left(\mathrm{C}_{18: 3}\right)$ & 42.7 \\
Linoleic acid $\left(\mathrm{C}_{18: 2}\right)$ & 13.4 \\
Oleic acid $\left(\mathrm{C}_{18: 1}\right)$ & 6.8 \\
Stearic acid $\left(\mathrm{C}_{18: 0}\right)$ & 4.1 \\
Arachidic acid $\left(\mathrm{C}_{20: 0}\right)$ & $\operatorname{tr}$ \\
Behenic acid $\left(\mathrm{C}_{22: 0}\right)$ & 1.6 \\
Tetracosanoic acid $\left(\mathrm{C}_{24: 0}\right)$ & $\operatorname{tr}$ \\
\hline Total saturation & 37.0 \\
Total unsaturation & 62.9 \\
Saturation/Unsaturation & 0.59 \\
L/O & 1.97 \\
\hline
\end{tabular}

${ }^{a} \mathrm{~L} / \mathrm{O}$ : linoleic acid-oleic acid ratio.

${ }^{\mathrm{b}}$ tr: trace

\subsection{Total phenolic and total flavonoid contents}

Phenolic compounds have antioxidant properties due to their ability to act as hydrogen donor and metal chelating [27]. Flavonoids are phenolic compounds widely distributed in plants and create a significant portion of the human diet
$[28,29]$. The acetone extract of $S$. pisidica has the highest amount of the total phenolic content $(100.24 \pm 1.06 \mu \mathrm{g}$ PEs/ $\mathrm{mg}$ ) while the methanol extract has the highest amount of the total flavonoid content $(43.75 \pm 0.20 \mu \mathrm{g}$ QEs/mg). The total phenolic contents of extracts of $S$. pisidica were found in the following order: acetone $>$ methanol $>$ hexane. The total flavonoid contents of extracts of $S$. pisidica were decreased in the order of methanol $>$ acetone $>$ hexane. In addition, the methanol extract of S. pisidica with higher concentrations of flavonoid contents showed the highest activity in all antioxidant activity assays except metal chelating assay (Table 3).

Table 3. Total phenolic and total flavonoid contents of the extracts of Sideritis pisidica ${ }^{\text {a }}$

\begin{tabular}{lll}
\hline Extracts & $\begin{array}{l}\text { Total phenolic contents } \\
\mu \mathrm{g} \text { PEs/mg extracts }\end{array}$ & $\begin{array}{l}\text { Total flavonoid contents } \\
\mu g \text { QEs/mg extract }\end{array}$ \\
\hline Hexane & $20.40 \pm 0.65$ & $30.66 \pm 0.81$ \\
Acetone & $100.24 \pm 1.06$ & $34.48 \pm 0.33$ \\
Methanol & $28.09 \pm 0.69$ & $43.75 \pm 0.20$ \\
\hline
\end{tabular}

a Values expressed are means \pm S.E.M. of three parallel measurements. $(\mathrm{p}<0.05)$

${ }^{\mathrm{b}}$ PEs, pyrocatechol equivalents.

${ }^{\mathrm{c}} \mathrm{QEs}$, quercetin equivalents.

\subsection{Antioxidant activity}

Many studies demonstrate that antioxidants protect against the chronic disease and aging by inhibiting or reducing the oxidation processes that produce free radicals [30]. In order to determine the antioxidant activity of the essential oil and the extracts of $S$. pisidica, lipid peroxidation inhibition by $\beta$-carotene-linoleic acid, DPPH free radical scavenging, ABTS cation radical scavenging, CUPRAC, and metal chelating assays were used. The antioxidant activities of the essential oil and the extracts of $S$. pisidica compared with BHA, $\alpha$-tocopherol and EDTA were given in Table 4. The essential oil and the extracts of S. pisidica were tested at different concentrations and $\mathrm{IC}_{50}$ values determined.

In $\beta$-carotene-linoleic acid, DPPH', ABTS ${ }^{+}$, and CUPRAC assays, the methanol extract showed the highest activity with $\mathrm{IC}_{50}$ values of $17.81 \pm 1.23,39.07 \pm 0.37,23.75 \pm 0.09,55.90 \pm 0.02$ $\mu \mathrm{g} / \mathrm{mL}$, respectively. The methanol extract showed very close radical scavenging activity to that of $\alpha$-tocopherol in DPPH assay while it exhibited the highest activity, even higher than that of $\alpha$-tocopherol in ABTS ${ }^{++}$, and CUPRAC assays (Table 4). These results suggest that the best antioxidant activity obtained with the methanol extract could be responsible for 
Table 4. Antioxidant activity of the essential oil and extracts of Sideritis pisidica by $\beta$-Carotene-linoleic acid, DPPH', ABTS ${ }^{+}$, CUPRAC and metal chelating assays ${ }^{a}$

\begin{tabular}{|c|c|c|c|c|c|c|}
\hline \multicolumn{7}{|c|}{ Antioxidant Activity } \\
\hline & & $\begin{array}{c}\beta \text {-Carotene- } \\
\text { linoleic acid assay }\end{array}$ & DPPH• assay & ABTS•+ assay & CUPRAC assay & $\begin{array}{c}\text { Metal chelating } \\
\text { assay }\end{array}$ \\
\hline & & $\mathrm{IC}_{50}(\mu \mathrm{g} / \mathrm{mL})$ & $\mathrm{IC}_{50}(\mu \mathrm{g} / \mathrm{mL})$ & $\mathrm{IC}_{50}(\mu \mathrm{g} / \mathrm{mL})$ & $\mathrm{A}_{0.50}(\mu \mathrm{g} / \mathrm{mL})^{\mathrm{b}}$ & $\mathrm{IC}_{50}(\mu \mathrm{g} / \mathrm{mL})$ \\
\hline \multirow{4}{*}{ S. pisidica } & Essential oil & $>200$ & $6.52 \pm 0.58^{c}$ & $>200$ & $>200$ & $N A^{\mathrm{e}}$ \\
\hline & Hexane extract & $89.34 \pm 0.57$ & $>200$ & $>200$ & $160.08 \pm 0.09$ & $22.97 \pm 1.36$ \\
\hline & Acetone extract & $24.44 \pm 0.48$ & $187.51 \pm 0.25$ & $86.20 \pm 1.13$ & $112.12 \pm 0.11$ & $57.98 \pm 0.70$ \\
\hline & Methanol extract & $17.81 \pm 1.23$ & $39.07 \pm 0.37$ & $23.75 \pm 0.09$ & $55.90 \pm 0.02$ & $71.93 \pm 0.88$ \\
\hline \multirow{3}{*}{ Standards } & $a$-Tocopherol ${ }^{\mathrm{d}}$ & $2.10 \pm 0.08$ & $37.20 \pm 0.41$ & $38.51 \pm 0.54$ & $66.72 \pm 0.81$ & $N T$ \\
\hline & $\mathrm{BHA}^{\mathrm{d}}$ & $1.34 \pm 0.04$ & $19.80 \pm 0.36$ & $11.82 \pm 0.09$ & $24.40 \pm 0.69$ & NT \\
\hline & EDTA $^{\mathrm{d}}$ & $N T^{\mathrm{f}}$ & NT & NT & NT & $3.47 \pm 0.16$ \\
\hline
\end{tabular}

${ }^{\mathrm{a}} \mathrm{IC}_{50}$ values represent the means \pm SEM of three parallel measurements $(p<0.05)$.

${ }^{\mathrm{b}} \mathrm{A}_{0.50}$ values represent the means \pm SEM of three parallel measurements $(p<0.05)$.

c $\%$ inhibition at $200 \mu \mathrm{g} / \mathrm{mL}$ concentration of the essential oil of Sideritis pisidica.

${ }^{\mathrm{d}}$ Reference compound. ${ }^{\mathrm{e}} N A$ : not active ${ }^{\mathrm{f}} \mathrm{NT}$ : not tested

BHA: butylatedhydroxyl anisole; EDTA: Ethylenediaminetetraacetic acid

its high level of total flavonoid content. In metal chelating assay, the highest activity was found in the hexane extract $\left(\mathrm{IC}_{50}: 22.97 \pm 1.36 \mu \mathrm{g} / \mathrm{mL}\right.$ ) and followed by the acetone extract $\left(\mathrm{IC}_{50}: 57.98 \pm 0.70 \mu \mathrm{g} / \mathrm{mL}\right)$. Non-phenolic components in the hexane extracts could be responsible for the observed metal chelating activity. The essential oil exhibited no any chelating activity (Table 4).

\subsection{Anticholinesterase activity}

Recent studies show that compound having acted as antioxidants may be used in the treatment of neuronal diseases [31]. Table 5 shows the acetylcholinesterase (AChE) and butyrylcholinesterase (BChE) inhibitory activities of the essential oil and extracts of S. pisidica compared with that of galantamine - that is used as a standard drug for the treatment of mild Alzheimer's disease.

The hexane extract $(62.54 \pm 0.88 \%)$ of $S$. pisidica exhibited high activity while the acetone and methanol extract were found to be inactive against AChE enzyme. The essential oil $(58.37 \pm 1.03 \%)$ was found as the most active against $\mathrm{BChE}$ enzyme. Also, the hexane and acetone extract of S. pisidica showed moderate inhibitory activity against $\mathrm{BChE}$ enzyme with inhibition \% values at $200 \mu \mathrm{g} / \mathrm{mL}$ concentration of $47.47 \pm 0.98 \%$ and $43.43 \pm 1.10$, respectively (Table 5 ).

\subsection{Anti-urease activity}

Urease has a significant role in the pathogenesis of gastric and peptic ulcers and cancer due to cause to survive
Helicobacter pylori in the acidic environment of the stomach. Besides, urease induces infections and urolithiasis by Proteus mirabilis and Yersinia enterocolitica, infection-induced acute pyelonephritis and reactive arthritis [32]. Urease inhibitors have attracted much attention as potential drugs. Table 5 shows inhibition \% values at $200 \mu \mathrm{g} / \mathrm{mL}$ concentration of the essential oil and the extracts of $S$. pisidica for anti-urease activity. Against urease enzyme, the hexane extract of $S$. pisidica $(78.93 \pm 0.17 \%)$ exhibited near activity to thiourea $(88.76 \pm 0.22 \%)$ used as a standard and followed by the methanol extract $(66.64 \pm 1.03 \%)$.

\section{Conclusion}

This is the first study to investigate the antioxidant, anticholinesterase and anti-urease activities of the essential oil and the hexane, acetone and methanol extracts of an endemic species S. pisidica from Turkey with the total phenolic and flavonoid contents. The methanol extract had the highest total flavonoid content and the best antioxidant activity in $\beta$-carotene-linoleic acid, $\mathrm{DPPH}^{\circ}, \mathrm{ABTS}^{-+}$, and CUPRAC assays. Also, the hexane extract was found to be significantly active in metal chelating assay, urease and acetylcholinesterase inhibitory activities. Thirty-one compounds were identified in the essential oil representing 99.9\% of the total oil; the major compounds were $\delta$-cadinene (19.5\%), T-cadinol (16.7\%) and $\beta$-cubebene (10.4\%). The most abundant fatty acids were found as linolenic (42.7 \%), palmitic (31.3\%) and linoleic (13.4\%) acids. 
Table 5. Anticholinesterase and anti-urease activities of the essential oil and the extracts of Sideritis pisidica ${ }^{\mathrm{a}}$

\begin{tabular}{|c|c|c|c|c|}
\hline \multirow{2}{*}{ Sideritis species } & & \multicolumn{2}{|c|}{ Cholinesterase Inhibitory Activity } & \multirow{2}{*}{$\begin{array}{c}\text { Urease Inhibitory Activity } \\
\text { Urease assay }\end{array}$} \\
\hline & & AChE assay & BChE assay & \\
\hline \multirow{4}{*}{ S. pisidica } & Essential oil & $11.60 \pm 1.20$ & $58.37 \pm 1.03$ & $7.88 \pm 0.22$ \\
\hline & Hexane extract & $62.54 \pm 0.88$ & $47.47 \pm 0.98$ & $78.93 \pm 0.17$ \\
\hline & Acetone extract & $N A^{\mathrm{c}}$ & $43.43 \pm 1.10$ & $43.21 \pm 0.28$ \\
\hline & Methanol extract & $N A$ & $16.35 \pm 0.91$ & $66.64 \pm 1.03$ \\
\hline \multirow[t]{2}{*}{ Standards } & Galantamine ${ }^{\mathrm{b}}$ & $80.41 \pm 0.98$ & $82.23 \pm 0.67$ & NT \\
\hline & Thiourea $^{\mathrm{b}}$ & NT & NT & $88.76 \pm 0.22$ \\
\hline
\end{tabular}

${ }^{\mathrm{a}}(\%)$ inhibition at $200 \mu \mathrm{g} / \mathrm{mL}$ concentration values represent the means \pm S.E.M. of three parallel measurements $(p<0.05)$. ${ }^{\mathrm{b}}$ Reference compounds. ${ }^{\mathrm{c}} \mathrm{NA}$ : not active. ${ }^{\mathrm{d}} \mathrm{NT}$ : not tested.

The results show that Sideritis pisidica could be used as a potential source of natural products in the food and pharmaceutical areas. However, further investigations are recommended including isolation of new drug candidates from this species as well as in vitro and in vivo tests to explore the activity in biological systems.

\section{Materials and Methods}

\subsection{Plant material}

The aerial part of S. pisidica was collected from Muğla, Turkey in 2013. The plant was identified by Dr. Hasan Yildirim at Ege University, Izmir, Turkey. The voucher specimen has been deposited at the herbarium of Ege University with voucher no EGE42371.

\subsection{Instruments and chemicals}

Bioactivity measurements were carried out on a 96-well microplate reader, SpectraMax 340PC384 (Molecular Devices, Silicon Valley, CA). The measurements and calculations of the activity results were evaluated by using Softmax PRO v5.2 software (Molecular Devices, Silicon Valley, CA). Analyses of chemical composition of the essential oils and fatty acids were performed using GC (Shimadzu GC-17 AAF, V3, 230V series gas chromatography, Japan) and GC/MS (Varian Saturn 2100T, USA).

Pyrocatechol, quercetin, $n$-hexane, methanol, ethanol, ferrous chloride, copper (II) chloride and ethylenediaminetetraacetic acid (EDTA) were purchased from E. Merck (Darmstadt, Germany). Butylatedhydroxyl anisole (BHA), $\alpha$-tocopherol, $\beta$-carotene, polyoxyethylene sorbitan monopalmitate (Tween-40), linoleic acid, Folin-Ciocalteu's reagent (FCR), neocuproine, 1,1-diphenyl-2-picryl-hydrazyl (DPPH), 2,2'-azino bis (3-ethylbenzothiazoline-6-sulfonic acid) diammonium salt (ABTS), 3-(2-pyridyl)-5,6-di(2-furyl)1,2,4-triazine-5',5"-disulfonic acid disodium salt (Ferene), acetylcholinesterase (AChE) from electric eel (TypeVI-S, EC 3.1.1.7, 425.84 U/mg, Sigma, St. Louis, MO), butyrylcholinesterase (BChE) from horse serum (EC 3.1.1.8, 11.4 U/mg, Sigma, St. Louis, MO), ), urease [TypeIII from Jack Beans, EC 232-656-0, 20990 U/g solid], 5,5'-dithiobis(2-nitrobenzoic) acid (DTNB), galantamine, thiourea, acetylthiocholine iodide, and butyrylthiocholine chloride were purchased from Sigma Chemical Co. (SigmaAldrich GmbH, Sternheim, Germany). All other chemicals and solvents were of analytical grade.

\subsection{Extraction}

The aerial part of $S$. pisidica ( $430 \mathrm{~g}$ ) was extracted separately with $2.5 \mathrm{~L}$ hexane, acetone and methanol, respectively at room temperature for $24 \mathrm{~h}$ and four times. Solvents were removed with a rotary evaporator. All extracts were stored at $+4^{\circ} \mathrm{C}$ until analysis.

\subsection{Isolation of the essential oil}

The essential oil of dried aerial parts of S. pisidica was obtained by hydrodistillation in a Clevenger type apparatus for $4 \mathrm{~h}$. The oil was dried over anhydrous sodium sulphate and stored under $+4^{\circ} \mathrm{C}$ until analysis.

\subsection{Analysis of the essential oil}

\subsubsection{Gas chromatography (GC-FID)}

A Flame Ionization Detector (FID) and a DB-5 fused silica capillary non-polar column ( $30 \mathrm{~m} \times 0.25$ id., film thickness 
$0.25 \mu \mathrm{m}$ ) were used for GC analyses. The injector temperature and detector temperature were adjusted $250{ }^{\circ} \mathrm{C}$ and $270{ }^{\circ} \mathrm{C}$, respectively. Carrier gas was $\mathrm{He}$ at a flow rate of $1.4 \mathrm{~mL} /$ min. Sample size was $1.0 \mu \mathrm{L}$ with a split ratio of $20: 1$. The initial oven temperature was held at $60{ }^{\circ} \mathrm{C}$ for $5 \mathrm{~min}$, then increased up to $240{ }^{\circ} \mathrm{C}$ with $4{ }^{\circ} \mathrm{C} / \mathrm{min}$ increments and held at this temperature for $10 \mathrm{~min}$. The percentage composition of the essential oil was determined with GC solution computer program.

\subsubsection{Gas chromatography /mass spectrometry (GC/MS)}

An Ion trap MS spectrometer and a DB-5 MS fused silica nonpolar capillary column $(30 \mathrm{~m} \times 0.25 \mathrm{~mm}$ ID, film thickness $0.25 \mu \mathrm{m}$ ) were used for the GC/MS analyses. Carrier gas was helium at a flow rate of $1.4 \mathrm{~mL} / \mathrm{min}$. The oven temperature was held at $60^{\circ} \mathrm{C}$ for $5 \mathrm{~min}$, then increased up to $240^{\circ} \mathrm{C}$ with $4^{\circ} \mathrm{C} / \mathrm{min}$ increments and held at this temperature for 10 min. Injector and MS transfer line temperatures were set at $220^{\circ} \mathrm{C}$ and $290^{\circ} \mathrm{C}$, respectively. Ion source temperature was $200^{\circ} \mathrm{C}$. The injection volume was $0.2 \mu \mathrm{L}$ with a split ratio of 1:20. EI-MS measurements were taken at $70 \mathrm{eV}$ ionization energy. Mass range was from $\mathrm{m} / \mathrm{z} 28$ to $650 \mathrm{amu}$. Scan time $0.5 \mathrm{~s}$ with 0.1 inter scan delays. Identification of components of the essential oils was based on GC retention indices and computer matching with the Wiley, NIST-2005 and TRLIB Library as well as by comparison of the fragmentation patterns of the mass spectra with those reported in the literature [33] and whenever possible, by co-injection with authentic compounds.

\subsection{Analysis of fatty acids}

The n-hexane extract was dissolved in $0.5 \mathrm{M} \mathrm{NaOH}(2 \mathrm{~mL})$ in a $25 \mathrm{~mL}$ flask. After the flask was heated in a water bath $\left(50^{\circ} \mathrm{C}\right)$, then $2 \mathrm{~mL} \mathrm{BF}_{3}: \mathrm{MeOH}$ was added. The mixture was boiled for 2 minutes, and then the mixture was left until it cooled down, and then the volume was completed to $25 \mathrm{~mL}$ with saturated $\mathrm{NaCl}$ solution. Esters were extracted with n-hexane; thus, the organic layer was separated. The hexane layer was washed with a potassium bicarbonate solution (4 $\mathrm{mL}, 2 \%$ ) and dried with anhydrous $\mathrm{Na}_{2} \mathrm{SO}_{4}$ and filtered. The organic solvent was removed under reduced pressure by a rotary evaporator to give methyl esters of fatty acid. Derivatization of methyl esters of fatty acids was carried out according to our previous method [34]. Qualitative and quantitative analysis of the fatty acid esters were performed by GC and GC/MSD as reported previously [35].

\subsection{Total phenolic and flavonoid contents}

The phenolic content in the extracts were expressed as microgram of pyrocatechol equivalents (PEs), determined with FCR according to the method of Slinkard \& Singleton [36] as described in the literature. The phenolic contents were calculated according to the following equation that was obtained from standard pyrocatechol graph:

Absorbance $=0.017[$ pyrocatechol $(\mu \mathrm{g})]+0.0025\left(r^{2}, 0: 9996\right)$

Measurement of flavonoid content of the extracts was based on the aluminum nitrate method [37], and results were expressed as microgram of quercetin equivalents. The flavonoid contents were calculated according to following equation that was obtained from the standard quercetin graph:

Absorbance $=0.019[$ quercetin $(\mu \mathrm{g})]-0.035\left(r^{2}, 0: 9985\right)$

\subsection{Antioxidant activity}

Total antioxidant activity by $\beta$-carotene-linoleic acid test [38], DPPH' free radical scavenging activity [38], ABTS $^{\bullet+}$ cation radical scavenging activity [38], CUPRAC antioxidant activity [38], Metal chelating activity [38] were determined according to our reported procedures with slight modifications [39]. The sample concentration providing $50 \%$ inhibition activity $\left(\mathrm{IC}_{50} \mu \mathrm{g} / \mathrm{mL}\right)$ was calculated from the graph of antioxidant activity percentages (Inhibition \%) against sample concentrations $(\mu \mathrm{g} / \mathrm{mL})$. The sample concentration having 0.50 absorbance $\left(\mathrm{A}_{0.5}\right)$ was calculated from the plot of CUPRAC absorbance against sample concentration.

\subsection{Anticholinesterase activity}

Acetylcholinesterase and butyrylcholinesterase enzymes inhibitory activities were measured the spectrophotometric method developed by Ellman et al. [40] with slight modifications [38]. Galantamine was used as reference compound. The results were given as inhibition percentage (\%) of the enzyme at $200 \mu \mathrm{g} / \mathrm{mL}$ concentration of the extracts and essential oil.

\subsection{Anti-urease activity}

Anti-urease activity was determined by measuring ammonia production using the indophenol method as described by Weatherburn (1967) [41]. Briefly, solution for the reaction was comprised of urease enzyme (Jack bean source $25 \mu \mathrm{L}$ ), 50 $\mu \mathrm{L}$ of urea $(100 \mathrm{mM})$ and $100 \mathrm{mM}$ sodium phosphate buffer 
( $\mathrm{pH}$ 8.2). The reaction solution along with test samples (10 $\mu \mathrm{L}, 1 \mathrm{mM}$ ) was incubated at $30^{\circ} \mathrm{C}$ for 15 minutes in 96 -well plate. Simply $45 \mu \mathrm{L}$ of $1 \%(\mathrm{w} / \mathrm{v})$ phenol reagent, alkali reagent $(70 \mu \mathrm{L})$ and sodium nitroprusside $0.005 \%(\mathrm{w} / \mathrm{v})$ was added to each well. After $50 \mathrm{~min}$ of incubation, increase in absorbance was measured with the of micro plate reader at $630 \mathrm{~nm}$. Thiourea was used as reference compound. The results were given as inhibition percentage (\%) of the enzyme at $200 \mu \mathrm{g} /$ $\mathrm{mL}$ concentration of the extracts and essential oil.

\subsection{Statistical analysis}

All data on the antioxidant, anticholinesterase and antiurease activity tests were the averages of three parallel sample measurements. The data were recorded as the mean \pm S.E.M. Significant differences between the means were determined by student's $t$ test, and $p$ values $<0.05$ were regarded as significant.

\section{Authorship statement}

Author contributions: Concept - E.D., G.TÇ., M.E.D.; Design - E.D., G.TÇ., M.E.D.; Supervision - G.TÇ., M.E.D.; Resource - G.TÇ., M.E.D.; Materials - H.Y., M.E.D.; Data Collection and/or Processing - E.D., G.TÇ., H.Y.; Analysis and/or Interpretation - E.D., G.TÇ.; Literature Search - E.D., G.TÇ., M.E.D.; Writing - E.D., G.TÇ.; Critical Reviews E.D., G.TÇ., M.E.D.

\section{Conflict of interest statement}

The authors declared no conflict of interest in the manuscript.

\section{References}

1. Aligiannis N, Kalpoutzakis E, Chinou IB, Mitakou S, Gika E, Tsarbopoulos A. Composition and antimicrobial activity of the essential oils of five taxa of Sideritis from Greece. J Agric Food Chem 2001; 49: 811-5.

2. Aslan I, Kılıc T, Gören A, Topçu G. Toxicity of acetone extract of Sideritis trojana and 7-epicandicandiol, 7-epicandicandiol diacetate and 18-acetylsideroxol against stored pests Acanthoscelides obtectus (Say), Sitophilus granarius (L.) and Ephestia kuehniella (Zell.). Ind Crops Prod 2006; 23: 171-6.

3. Güven A, Houghton PJ, Duman H, Coşkun M, Şahin P. Antioxidant activity studies on selected Sideritis species native to Turkey. Pharm Biol 2005; 43: 173-7.

4. Baytop T. Türkçe bitki adları sözlüğü. Ankara, Türk Tarih Kurumu Basımevi 1997; İkinci baskı.

5. Baytop T. Türkiye’ de bitkiler ile tedavi (Geçmişte ve Bugün).
İstanbul, Nobel Kitabevi 1999; İkinci bask1.

6. Sagdic O, Aksoy A, Ozkan G, Ekici L, Albayrak S. Biological activities of the extracts of two endemic Sideritis species in Turkey. Innovat Food Sci Emerg Tech 2008; 9: 80-4.

7. Bojovic D, Jankovic S, Potpara Z, Tadic V. Summary of the phytochemical research performed to date on Sideritis species. Serbian J Exp Clin Res 2011; 12: 109-22.

8. Erkan N, Cetin H, Ayranci E. Antioxidant activities of Sideritis congesta Davis et Huber-Morath and Sideritis arguta Boiss et Heldr: Identification of free flavonoids and cinnamic acid derivatives. Food Res Int 2011; 44: 297-303.

9. Todorova M, Trendafilova A. Sideritis scardica Griseb., an endemic species of Balkan peninsula: Traditional uses, cultivation, chemical composition, biological activity. J Ethnopharmacol 2014; 15: 256-65.

10. Aboutabl EA, Nassar MI, Elsakhawy FM, Maklad YA, Osman AF, El-Khrisy EAM. Phytochemical and pharmacological studies on Sideritis taurica Stephan ex Wild. J Ethnopharmacol 2002; 82: 177-84.

11. Topçu G, Ertaş A, Özturk M, Dinçel D, Kılıç T, Halfon B. Ent-kaurane diterpenoids isolated from Sideritis congesta. Phytochem Lett 2011; 4: 436-9.

12. Ozkan G. Comparison of antioxidant phenolics of ethanolic extracts and aqueous infusions from Sideritis species. Asian J Chem 2009; 21: 1024-8.

13. Kirmizibekmez H, Ariburnu E, Masullo M, Festa M, Capasso A, Yesilada E, Piacente S. Iridoid, phenylethanoid and flavonoid glycosides from Sideritis trojana. Fitoterapia 2012; 83: 130-6.

14. Zengin G, Sarikürkcü C, Aktümsek A, Ceylan R. Sideritis galatica Bornm.: A source of multifunctional agents for the management of oxidative damage, Alzheimer's's and diabetes mellitus. J Func Foods 2014; 11: 538-47.

15. Hernández-Pérez M, Rabanal Gallego M. Analgesic and antiinflammatory properties of Sideritis lotsyi var. mascaensis. Phytother Res 2002; 16: 264-6.

16. Loğoğlu E, Arslan S, Öktemer A, Sakiyan I. Biological activities of some natural compounds from Sideritis sipylea Boiss. Phytother Res 2006; 20: 294-7.

17. Basile A, Senatore F, Gargano R, Sorbo S, Del Pezzo M, Lavitola A, Ritieni A, Bruno M, Spatuzzi D, Rigano D, Vuotto ML. Antibacterial and antioxidant activities in Sideritis italica (Miller) Greuter et Burdet essential oils. J Ethnopharmacol 2006; 107: 240-8.

18. Köse EO, Deniz TG, Sarikürkcü C, Aktas Ö, Yavuz M. Chemical composition, antimicrobial and antioxidant activities of the essential oils of Sideritis erythrantha Boiss. and Heldr. (var. erythrantha and var. cedretorum P.H. Davis) endemic in Turkey. Food Chem Toxicol 2010; 48: 2960-5.

19. Kirimer N, Baser KHC, Demirci B, Duman H. Essential oils of Sideritis species of Turkey belonging to the section Empedoclia. Chem Nat Compd 2004; 40: 19-23.

20. Ozkan G, Krüger H, Schulz H, Özcan M. Essential oil composition of three Sideritis species used as herbal teas in Turkey. J Essent Oil Bear Pl 2005; 8: 173-7.

21. Ozel MZ, Kutlular O. Regional changes in the chemical composition of essential oils of Salvia fruticosa and Sideritis pisidica using superheated water extraction. Anal Chem Lett 
2011; $1: 34-42$.

22. Ergun M, Ergun N, Ozbay N. Analysis of volatile constituents of Sideritis pisidica Boiss. \& Heldr. by head space gas chromatography mass spectrometry (HS-GC/MS). Z Arznei.Gewurzpfla 2016; 21: 68-72.

23. Ertan A, Azcan B, Demirci N, Baser KHC. Fatty acid composition of Sideritis Species. Chem Nat Compd 2001; 37: 301-3.

24. Erdogan-Orhan I, Baki E, Şenol R, Yilmaz G. Sage-called plant species sold in Turkey and their antioxidant activities. J Serb Chem Soc 2010; 75: 1491-1501.

25. Mateo C, Calderón J, Sanz J. Essential oils of some Sideritis Species from central and southern Spain. Phytochemistry 1988; 27: 151-3.

26. Maffei M, Scannerini S. Fatty acid variability from non-polar lipids in some Lamiaceae. Bio Chem Syst Ecol 1993; 21: 47586.

27. Pereira DM, Valentão P, Pereira JA, Andrade PD. Phenolics: From chemistry to biology. Molecules 2009; 14: 2202-11.

28. Jovanovic SC, Steenken S, Tosic M, Marjanovic B, Simic MG. Flavonoids as antioxidants. J Am Chem Soc 1994; 116: 484651.

29. Hertog MGL, Hollman PCH, Venema DP. Optimization of a quantitative HPLC determination of potentially anticarcinogenic flavonoids in vegetables and fruits. J Agric Food Chem 1993; 40: 1591-8.

30. Tabet N. Acetylcholinesterase inhibitors for Alzheimer's disease: Antiinflammatories in acetylcholine clothing. Age Ageing 2006; 35: 336-8.

31. Atta-ur-Rahman, Choudhary MI. Bioactive natural products as a potential source of new pharmacophores. A theory of memory. Pure Appl Chem 2001; 73: 555-60.

32. Arfan M, Ali M, Ahmad H, Anis I, Khan A, Choudhary MI, Shah MR. Urease inhibitors from Hypericum oblongifolium
Wall. J Enzym Inhib Med Chem 2010; 25: 296-9.

33. Adams RP. Identification of essential oil components by gas chromatography/quadrupole mass spectrometry. J Am Soc Mass Spectr 2007; 16: 1902-3.

34. Tel G, Ozturk M, Duru ME, Dogan B, Harmandar M. Fatty acid composition, antioxidant, anticholinesterase and tyrosinase inhibitory activities of four Serratula species from Anatolia. Rec Nat Prod 2013; 7: 86-95.

35. Özturk M, Tel G, Aydoğmuş-Ozturk F, Duru ME. The cooking effect on two edible mushrooms in Anatolia: Fatty acid composition, total bioactive compounds, antioxidant and anticholinesterase activities. Rec Nat Prod 2014; 8: 189-94.

36. Slinkard K, Singleton VL. Total phenol analyses: Automation and comparison with manual methods. Am J Enol Viticult 1977; 28: 49-55.

37. Park YK, Koo MH, Ikegaki M, Contado JL. Comparison of the flavonoid aglycone contents of Apis mellifera propolis from various regions of Brazil. Braz Arch Biol Techn 1997; 40: 97 106.

38. Tel G, Apaydın M, Duru ME, Ozturk M. Antioxidant and cholinesterase inhibition activities of three Tricholoma species with total phenolic and flavonoid contents: The edible mushrooms from Anatolia. Food Anal Method 2012; 5: 495504.

39. Çayan F, Tel G, Duru ME, Öztürk M, Türkoğlu A, Harmandar M. Application of GC, GC-MSD, ICP-MS and spectrophotometric methods for the determination of chemical composition and in vitro bioactivities of Chroogomphus rutilus: The edible mushroom species. Food Anal Method 2014; 7: 449-58.

40. Ellman GL, Courtney KD, Andres V, Featherston RM. A new and rapid colorimetric determination of acetylcholinesterase activity. Biochem Pharmacol 1961; 7: 88-95.

41. Weatherburn MW. Phenol-hypochlorite reaction for determination of ammonia. Anal Chem 1967; 3: 971-4. 